\title{
Introduction
}

\section{New Directions for Refugee Policy: Of Curtains, Doors, and Locks}

\author{
Audrey Macklin
}

$\mathrm{H}$ alfway through the last century, Winston Churchill presaged one of the most profound transformations of the modern political map with the warning that "an iron curtain has descended" on Europe. This potent metaphor conjured up an impenetrable partition holding citizens of Eastern Europe captive to Communist regimes, depriving them of basic liberties. Subsequently, the Berlin Wall became the physical representation of the abrogation of the fundamental right of exit for the people of Eastern Europe. Five years after Churchill's speech, the 1951 un Convention relating to the Status of Refugees entered into force. The convention's initial geographic limitation to Europe revealed the West's cold-war preoccupation with citizens under Communism. If they could escape-breach the wall, pass through the curtainthey were virtually assured of asylum.

In February 2001, on the eve of the 1951 convention's fiftieth anniversary, United Nations High Commissioner for Refugees Ruud Lubbers ironically (if inadvertently) recalled Churchill's metaphor. In response to the question of whether the European Union was doing enough to grapple with the problem of refugees, Lubbers replied, "No ... We are closing the curtains ... and saying there is no real problem there."

Fortress Europe has supplanted the Berlin Wall, and the locks barring exit from the east have been switched to bar entry to the west. In North America, Australia, and New Zealand the pattern is the same. The world's wealthiest nations want to prevent refugees from crossing into their territory uninvited, no matter where they come from, why they fled, or even whether the demographic self-interest of the country of asylum could actually benefit from the infusion of more people. Although Canada appears less draconian than some nations in dealing with claimants who actually arrive within its borders, it has also pioneered many deflection strategies. Moreover, Canada's relatively remoteness from the major refugee- and migrant-producing regions of the world means that (despite media reports to the contrary) it receives few undocumented migrants and refugee claimants in relative and absolute terms.

The embargo on refugees is accomplished in several ways. Refugees are excluded physically through interdiction and non-entrée policies, and discursively through their demonization as criminals and illegals. Restrictive eligibility requirements and narrow interpretations of the convention further limit access to refuge protection. Detention and limited assistance (or no assistance at all) while refugee determination is pending operate to socially marginalize refugee claimants within host countries.

These themes are repeated, with local variation, in legislation and institutional practice in the nation-states of North America, Europe, Australia, and New Zealand. In Canada, incremental changes in migration legislation since the mid-1980s were punctuated by judicial pronouncements demarcating the scope of fundamental rights available to non-citizens under the Canadian Charter of Rights and Freedoms. In the mid-1990s, momentum began building toward an overhaul of Canada's Immigration Act. In late 1997, a government-appointed legislative review committee issued a report entitled Not Just Numbers, whose tone and recommendations for reform reflected the neo-liberal discourse of economic globalization, privatization of the 
public sphere, and the application of private market norms to Canadian migration policy.

Following the usual round of consultations with several "stakeholders," the government issued a white paper in 1998 outlining the direction of future legislative reform in immigration. The process might have proceeded at the same steady pace, but as is so often the case in immigration policy, a single event catapulted immigration to the front page and legislative reform to the front burner: In the summer of 1999, four ships carrying almost six hundred migrants from Fujian, China, arrived off the coast of British Columbia. Virtually all aboard claimed refugee status.

There's something about people on boats that Canadians find deeply threatening: In 1914, the Komagata Maru spent months marooned in Vancouver Harbour with over two hundred South Asians aboard, British subjects denied their right to enter another of the king's dominions. In 1939, four hundred Jews aboard the St. Louis, desperately attempting to escape the Holocaust were four hundred too many Jews for Canada. In 1987, two boatloads of South Asians landing off the Atlantic Coast was enough to trigger an emergency session of Parliament to pass legislation to respond to the apparent crisis. Despite the fact that the Fujian migrants comprised a mere 2 per cent of Canada's annual intake of inland refugee claimants, the emotive force of boatloads of uninvited migrants washing ashore precipitated a moral panic that catalyzed the speedy introduction of a legislative package. Bill C-31 (The Immigration and Refugee Protection Act) highlighted deterrence, deflection, detention, and criminal penalties as easy remedies for the complex problems of irregular migration. The fact that refugees often have no alternative but to use the services of smugglers, and may also fall prey to traffickers, is submerged by powerful tropes featuring Canada as a country losing control of its borders and thus its sovereignty. On this telling, impoverished migrants are cast as invaders and Canada the victim as it defends its vulnerable borders against the foreign intruder.

The proposed legislation contained many other proposals directly or indirectly affecting refugees. These included modifications to the refugee determination process, the introduction of an internal appeal mechanism and pre-removal risk assessment, increased powers to find certain classes of refugee claimants ineligible for refugee protection, and changes to family sponsorship provisions. But just as external events thrust the new legislation onto the parliamentary agenda, so too did external forces take it off the table. An election was called in the fall of 2000, and Bill C-31 died on the order paper.

At the time of writing, the Liberal government has been returned to power, and the minister of Citizenship and Immigration has reintroduced the Immigration and Refugee Protection Act (now Bill c-11) in the latest parliamentary session. Although Bill C-11 differs in certain aspects from its predecessor, its essential elements remain unchanged.

The articles in this special issue of Refuge offer a diverse and stimulating array of perspectives from which to evaluate the direction of legislative reform in Canada.

Judith Kumin, the UNHCR representative in Canada, explains the impending Global Consultation Process initiated by the UNHCR to "revitalize the international protection regime and discuss measures to ensure international protection for all who need it." At a moment when more people than ever are "lost on earth," this sharing of ideas, information, and commitment between states, NGOS, and civil society is crucial and timely.

Refugee scholar Anthony Richmond revisits a thesis he explored in his 1994 book Global Apartheid: Refugees, Racism and the New World Order and asks whether anything has changed since the early 1990 . After comparing selected elements of the Canadian refugee system with the practices of the United States and Europe, his response is a tentative yes and no: Western industrial states remain willing in principle to accept small numbers of demonstrably desperate refugees from Africa and Asia, but the countervailing fear of opened floodgates has led to increasingly stringent measures of exclusion.

Jacqueline Oxman-Martinez, Andrea Martinez, and Jill Hanley report the findings of their study into trafficking in Canada and the implications of current legislative policy on refugees' ability to access protection. The authors place irregular migration into a global context, and take a critical approach to the trend revealed in Bill C-31, which focuses on border control and punitive measures at the expense of protecting the human rights of trafficked persons, including refugees.

Sunera Thobani pursues the theme of trafficking and smuggling from a feminist perspective. She illustrates that existing terms of entry for women structure and enable forms of trafficking, such as mail-order marriages, the sex trade, and live-in domestic work. Thobani argues that the current direction of law reform in Canada allows the state to pose as the protector of Canadians, while exacerbating the vulnerability of women who are trafficked, and doing nothing to alleviate the causes of trafficking or address the complicity of those Canadians who profit and benefit from the exploitation of trafficked workers.

Janet Dench addresses the evolution of Canadian interdiction policies up to and including Bill c-31, focusing on the detrimental impact of these practices on refugees' abil- 
ity to reach a safe haven. Dench situates her analysis of the impact of these policies on asylum seekers in the context of a broader critique of the international regime's failure to approach the issues of trafficking and smuggling from a human rights perspective, preferring instead to frame them as criminal matters. The result is an erasure of refugees, coupled with the collective demonization of those who resort to irregular migration as illegals and criminals.

Stephen Knight offers a timely and invaluable comparative perspective on border controls through his analysis of the U.S. "expedited removal" law. Knight describes how the heightened powers of immigration officers to detain and deport those found to lack valid or suitable travel documents, coupled with the virtual elimination of judicial review, has led to grave concerns about abuse of due process and profoundly unjust outcomes. Moreover, Knight illustrates that the U.S. "expedited removal" process also impedes Canadian-bound asylum seekers transiting through the United States, effectively compelling them to seek asylum in the U.S. Knight's analysis is a useful reminder that nation-states do not operate in a vacuum, and that the impact of national migration policies inevitably traverses borders, even as asylum seekers themselves cannot.

David Matas traces the tortuous path of Canadian refugee determination-a system notable for both "complexity and unfairness"-from its inception to the latest proposals contained in Bill C-31. He offers an astute diagnosis of this dysfunctional combination, and assigns responsibility to Canada's overriding immigration objective of controlling borders.

Michael Bossin reviews the various provisions that restrict access of asylum seekers to refugee determination. After noting the deficiencies of overseas determinations at Canadian missions abroad, he turns his attention to the grounds for ineligibility under existing and proposed legislation. These include criminality, prior refusal of refugee protection, and prior abandonment or withdrawal of claims. Bossin highlights the potential for each of these grounds of ineligibility to deny a hearing into the merits of the claim of a person in need of refugee protection.

François Crépeau, Patricia Foxen, France Houle and Cécile Rousseau turn their lens onto the actual process of refugee determination, and adopt a behaviouralist methodology to expose serious concerns about the sensitivity and competence of some decision makers on Canada's Immigration and Refugee Board.

Michael Casasola's contribution examines Canada's refugee resettlement program. His review emphasizes the need for adaptability in the program to keep pace with the evolving global landscape. Casasola's examples draw our atten- tion to the relationship between the UNHCR and national governments in formulating and implementing programs that are responsive to urgent resettlement needs.

Robert Barsky stands back from the particulars of Bill C-31 and launches a broad and impassioned denunciation of the statist conception underlying borders, arguing that "people have the inalienable right to move around as they wish, for whatever reason they think appropriate. Period." He uses aspects of Bill C- 31 as an illustration of the deficiencies and injustices of any system premised on a presumptive right to exclude the Other.

Colin Harvey reminds us of the potential and the limitations of national and supra-national human rights norms to complement refugee law and contest the "race to the bottom" approach to refugee protection among Western nations. He turns to the U.K. Human Rights Act, 1998, which incorporates into domestic law an interpretive presumption in favour of significant elements of the European Convention on Human Rights. Harvey surveys some jurisprudence of the European Court of Human Rights on asylum as a way to explore the potential of human rights law to advance the human security of refugees and asylum seekers.

Joseph Rikhof's contribution on Canadian immigration policy on war crimes, terrorism, organized crime, and general criminality elaborates upon the complex legal regime that regulates the substance and process of exclusionary provisions. His discussion sets the stage for considering how international law, politics, and human rights norms has shaped existing domestic law and how such forces may (or may not) constrain future developments.

Sharryn Aiken's article, the second of two parts, explores interpretations of terrorism by the Federal Court of Canada, in the context of numerous provisions in the Canadian Immigration Act for exclusion and ineligibility. Her critique focuses in particular on the Suresh case, wherein a Sri Lankan refugee was determined to pose a danger to the security of Canada, and therefore liable to refoulement, despite evidence that he would face serious risk of torture if returned to Sri Lanka. This case is en route to the Supreme Court of Canada where, among other things, the court will have the opportunity to elaborate on the interaction of Canadian refugee policy, the Canadian Charter of Rights and Freedoms, and Canada's international obligations on refoulement and torture.

The contributors to this issue of Refuge speak from a wide range of vantage points, and include scholars, advocates, representatives of international organizations, and government lawyers. Many participated in the consultation after introduction of Bill c-31. In addition to their geographic range, the authors' insightful—often incisive- 
appraisals of trends in legislation and policy span the various institutional sites of law creation and implementation (Parliament, Congress, the UN, courts, bureaucracy) as well as different methodological approaches (analytical, behavioural, jurisprudential, feminist, theoretical).

Some contemporary migration literature tends to diminish the role of the state in directing and regulating migration flows. Economic globalization and supra-national human rights norms are projected as exerting significant constraints on the abilities of individual states to police bodies legally and practically. The articles in this volume, with their attention to myriad ways in which national legal regimes affect forced migrants in general, and refugees in particular, serves as an important reminder of the resilience and the coercive power of state migration policies and practices. In case of any lingering doubt, just ask any refugee.

Audrey Macklin is associate professor of law at University of Toronto. Her research areas include immigration and refugee law, culture and law, and feminist jurisprudence. From 1994 to 1996, she was a member of the Convention Refugee Determination Division of Canada's Immigration and Refugee Board. 